CIC. Cuadernos de Información y Comunicación

ISSN: 1135-7791

http://dx.doi.org/10.5209/CIYC.55951

\title{
Presentación del número
}

\section{Eva Aladro Vico}

El número 22 de CIC Cuadernos de Información y Comunicación va destinado en su sección central a los denominados "Lenguajes Digitales". Presentamos un conjunto de contribuciones, de algunos autores consagrados, y otros completamente noveles, así como algunas traducciones de textos esenciales que están faltando en nuestra lengua, para acotar el fenómeno del surgimiento de un nuevo lenguaje o unos nuevos lenguajes, en el proceso amplio que se ha denominado de convergencia cultural y trascodificación digital, que caracteriza al siglo XXI.

Desde que Lev Manovich, a comienzos de ese siglo, pusiera la atención académica en el lenguaje de los nuevos medios de comunicación digitales, un verdadero ciclón comunicativo investigador ha generado este lenguaje de lenguajes que constituye la convergencia digital. Estamos ante el surgimiento incesante de un lenguaje humano nuevo, que se forma con los lenguajes de la comunicación que hemos compartido anteriormente, y cuya capacidad creativa y transformadora es inmensa. El fenómeno de fusión nuclear comunicacional es tan intenso que absorbe en su seno las formas culturales más variadas y sintetiza creaciones innumerables en un nuevo universo infinito y abierto para la comunicación global. En este número de CIC queremos abordar en forma perspectivística ese fenómeno, aportando distintos enfoques con los que interpretar los lenguajes digitales y sus constructos en incesante creación.

La revolución digital ha afectado de igual manera a la cultura como a las herramientas de la tecnología. Hallamos en todas partes metáforas y proyecciones constantes del fenómeno de fusiones y re-mediaciones, de composiciones mosaicas y de cartografías multidimensionales, que caracteriza al nuevo lenguaje digital. No hay un único fenómeno cultural con un epicentro que pueda estudiarse, como ocurrió hace siglos con la invención de la escritura, o de la imprenta, hitos a los que se compara el fenómeno excéntrico del surgimiento del lenguaje digital. La convergencia cultural digital no tiene un único eje, se manifiesta en constante transformación, en constante cambio de dimensiones, y afecta también a los espacios fuera de la Red, en el mundo offline, donde la recuperación y la vertebración de los espacios y entornos en nuevas superficies y dimensiones de experiencia es un reflejo, una adaptación, a cuanto ocurre en el medio digital. "Hay otros mundos, pero están en éste", decía el surrealista Paul Éluard en el siglo XX. "Hay otros mundos que cada día nacen de éste", cabría decir en el siglo en que vivimos.

Contamos ya con una evolución digital de más de veinte años, en la que es posible detectar las tendencias y fenómenos creativos esenciales, y estudiar y valorar su importancia. También es posible ya ver toda una gama de problemas y de perjuicios generados por la convergencia digital, por la mercantilización absoluta de las estruc- 
turas de las redes humanas, por la reversión generada por la infoxicación creciente, por la incidencia trágica de las formas alienantes de uso de la auto-imagen y el narcisimo pan-icónico. En este número, la revista CIC continúa con su diseño académico orientado a ofrecer un abanico de aportaciones de múltiple enfoque: desde textos magistrales de Manovich, Boczkowski, Zuckerman o Lovink, que continúan sus exploraciones sobre el lenguaje digital y sus usos periodísticos o sus consecuencias socio-políticas y culturales, hasta aportaciones de investigadores noveles como Blanes, Moreno o Daniel Alonso, en torno a fenómenos como las redes sociales, los selfies o autofotos y los videojuegos online. Investigadores del ámbito español, como García y Gertrúdix, Aladro o Vázquez Márquez, aportan sus líneas de trabajo en torno a las gramáticas digitales, sus lenguajes musicales o sus cartografías culturales. Algunos textos clásicos, como los análisis de las arquitecturas informacionales y la carga cognitiva en los hipertextos, de Jonassen y Sweller, se incluyen por primera vez en lengua hispana en el número, continuando nuestra tradición, muy querida y apreciada en el entorno de los expertos, de favorecer el intercambio internacional de teorías e investigaciones con el flujo de textos legendarios a nuestra lengua, mediante nuestra revista académica.

En este sentido incluimos, y por el bien de la homeostasis mediológica que tanto gustaba a McLuhan, un texto muy antiguo, de la antropóloga Ruth Benedict, titulado "Tazas de barro", como frontispicio a este número abalanzado sobre las mutaciones e innovaciones digitales. El texto de Benedict es una joya inédita en español escrita al comienzo del siglo XX. La antropóloga y poeta norteamericana inició con este artículo su fama como escritora e investigadora, bajo la influencia fundamental de Franz Boas, en el enfoque de la antropología de modelos culturales, que tanto influiría a su vez en Margaret Mead, y en Gregory Bateson también, y para la que es imposible separar las manifestaciones culturales de sus prácticas y su materialización. Como si fuera un cuento cuya moraleja no debemos olvidar, este bellísimo texto de Benedict debe recordarnos a los investigadores en comunicación que estudiamos formas culturales únicas de frágil esencia, a las que acercarse exige una infinita sutileza, la de una poetisa, o la de un monje meditativo, la del artista o el orfebre, y que cada forma cultural exige la cuidadosísima manipulación que impida que, rota para siempre por categorías rígidas o métodos insensibles, no quede memoria de la capacidad de transportar la vida que tiene cada una de ellas.

Hay algunas aportaciones añadidas a este conjunto que versan sobre fenómenos adicionales y adyacentes al mundo digital, como son las de Bernárdez, Mayoral o Revilla. Todas ellas tienen conexión de uno u otro modo con los nuevos lenguajes que han surgido a partir de la fusión tecnológica digital. Y todas las contribuciones, que en este número han sido muchas y variadas, servirán para reflexionar y prestar atención a ese nuevo lenguaje surgido de la digitalización, cuya finalidad es liberar a los individuos de sus barreras a la hora de humanizar y comunicar sus experiencias, y que precisa de urgentes interpretaciones para poder aprovechar las inmensas potencialidades en que podría desarrollarse y evitar que se convierta él mismo, cumpliendo la ley de la reversión Mcluhaniana, con su propio desarrollo, en su propio impedimento. 